\title{
Advancing traceability using DNA sequence on seafood product: fraudulence in shrimp crackers
}

\author{
MALA NURILMALA`, YOGHI AJITAMA, AGOES M JACOEB, AFKAR RONA INDARWATI, RONI NUGRAHA \\ Department of Aquatic Product Technology, Faculty of Fisheries and Marine Science, Institut Pertanian Bogor. Jl. Agatis, IPB Dramaga Campus, Bogor \\ 16680, West Jawa, Indonesia. Tel./fax.: +62-251-8622915, ^email: mnurilmala@apps.ipb.ac.id
}

Manuscript received: 18 September 2020. Revision accepted: 18 November 2020.

\begin{abstract}
Nurilmala M, Atjitama Y, Jacob AM, Indarwati AR, Nugraha R. 2020. Advancing traceability using DNA sequence on seafood product: fraudulence in shrimp crackers. Biodiversitas 21: 5650-5656. Shrimp crackers are snacks made from starch with the addition of shrimp and other ingredients. Authentication of shrimp crackers becomes a quality control method in line with its traceability since the morphological characters are not recognized in those products. The failure of the authentication will lead to adulteration of shrimp products. The study aimed to design shrimp-specific polymerase chain reaction (PCR) primers by and used them to authenticate shrimp cracker products to assure their traceability. The primers were designed from cytochrome oxidase subunit I (COI) gene with a GC content of $50 \%$ and a melting temperature of $57{ }^{\circ} \mathrm{C}$. The amplicon had a length of $613 \mathrm{bp}$. Fourteen shrimp crackers having DNA concentrations 0.3 to $8.1 \mathrm{ng} / \mu \mathrm{L}$ were evaluated. Eight out of fourteen DNA samples were successfully amplified using the specific primer and could be visualized on the agarose gel at 500-750 bp. Those DNA samples were identified belonging to shrimp species, namely Litopenaeus vannamei, Metapenaeus ensis, and Fenneropenaeus merguiensis with $95 \%$ to $100 \%$ identity. Meanwhile, the other six DNA samples underwent PCR using universal primers. One sample was amplified and identified as fish (Sphyraena flavicauda). These results indicate illegal substitution of shrimp using unidentified species occurred in shrimp crackers.
\end{abstract}

Keywords: adulteration, cytochrome oxidase subunit I, PCR, shrimp, specific primer

\section{INTRODUCTION}

Shrimp is one of the Indonesian export commodities other than tuna, seaweed, and crab. Shrimp production comes from wild population and aquaculture and their production volume is increasing every year, followed by the increased volume and value of shrimp exports. The export volume of Indonesian fishery products in March 2020 amounted to 105.20 thousand tons, and increased 4.89\% compared to exports in March 2019. The feature export commodity for fishery products is shrimp with a value of USD 466.24 million (37.56\%) (KKP 2020). Several shrimp species that dominate export commodities are vannamei shrimp (Litopenaeus vannamei), tiger shrimp (Penaeus monodon), and giant prawns (Macrobrachium rosenbergii).

One of the shrimp processed products that become an export commodity is shrimp crackers. They are snacks made from tapioca starch added with shrimp and other spices. Shrimp crackers have a distinctive taste and smell, uniform shape and size, and the color similar to very young boiled shrimp (Destrasia 2012). Authentication on shrimp cracker products is very important because morphological identification could not be done on shrimp cracker products that have undergone the processing and addition of other materials. The failure of the authentication mechanism will lead to adulteration of shrimp cracker products. The fraudulence of fishery products causes losses due to higher costs incurred for products that have been replaced with cheaper raw materials. These occur due to the high demand and value of several fish, for example the substitution of grouper (Epinephelinae spp.) with freshwater catfish (Pangasianodon hypophthalmus) (Calosso et al. 2020). The fraudulence cases have been reported on fish products (Xiong 2019), fish samples obtained in Brazil (Carvalho et al. 2015), canned fish products (Shokralla et al. 2015), and fish products in Italy (Corrado et al. 2016). Meanwhile, several studies have also reported adulteration of fish products in Indonesia, including the product of mackerel crackers (Maulid and Nurilmala 2015), canned tuna (Nurilmala et al. 2016), and shark products (Abdullah et al. 2020).

Authentication is needed to convince consumers of the accuracy of labeling on food products to confirm its traceability. DNA analysis such as conventional polymerase chain reaction (PCR) and quantitative PCR (qPCR) can be used as good methods of authentication in processed food products since DNA remains stable after undergoing food processing (Scarano and Rao 2014). DNA exists in most living cells, so identical information can be obtained in all parts of the sample with the same source (Paquin et al. 2014). The validated species from the mislabeled on commercial fish products can be achieved by DNA barcoding (Xiong 2019; Adibah et al. 2020). DNA barcoding techniques have been successfully used to identify canned fish products (Shokralla et al. 2015) and cooked products (Pollack et al. 2018). In addition, Barcaccia et al. (2015) reported the identification of food products with the addition of other materials of different species using DNA barcoding. 
Mitochondrial DNA (mtDNA) is often used in DNA barcoding of many organisms, including fish (Abdullah et al. 2019; Nurilmala et al. 2020) because of the relatively small genome size. Also, mtDNA undergoes faster evolution making it more effective for the identification of adjacent interspecies (Amaral et al. 2017). Cytochrome oxidase subunit I (COI), $16 \mathrm{~S}$, and $12 \mathrm{~S}$ ribosome subunits, as well as cytochrome $\mathrm{b}$ are the most widely used mtDNA for DNA barcoding (Ceruso et al. 2020; Hanifaturahmah et al. 2020). This study used COI gene from mitochondrial DNA as the target gene. The COI genes showed a global bio identification system of animals, a universal primer for a very strong COI gene (Palanisamy et al. 2020), and have a greater range of phylogenetic signals than other mitochondrial genes (Sutrisno 2015). This method, however, needs species-specific primers enabling the authentication of products from particular species. Thus, this study aimed to design shrimp-specific PCR primers and used the primers to authenticate shrimp cracker products to assure their traceability.

\section{MATERIALS AND METHODS}

\section{Sample collection and DNA isolation}

Fourteen shrimp crackers (KU I-KU XIV) with different brands were collected from traditional and modern markets in Bogor, West Java,-Indonesia. Six hundred $\mathrm{mg}$ of samples were crushed and the DNA samples from those crackers were isolated using Qiagen DNeasy Food Mericon following the manufacturer's instruction.

\section{Primer design}

Primer design was carried out by aligning shrimp cytochrome oxidase I (COI) sequences obtained from the National Center for Biotechnology Information (NCBI). The sequences were aligned using the BioEdit program and a conserved sequence of nucleotides was selected in all samples (Álvarez-Fernández 2013). The selected primers were then evaluated using the OligoEvaluator ${ }^{\mathrm{TM}}$ online software and checked with the Basic Local Alignment Search Tool (BLAST) for their specificity.

\section{DNA amplification}

Amplification of the COI gene segment was performed by Polymerase Chain Reaction (PCR) technique using the previously designed specific primer of COI gene and PCR mix (KAPA Taq PCR Kit, KapaBiosystem, Wilmington USA) on PCR machine (Integrated DNA Technologies, Singapore) (Nurilmala and Ochiai 2016). The PCR temperature conditions were pre-denaturation at $94{ }^{\circ} \mathrm{C}$ for 5 minutes, followed by 40 denaturation cycles at $94{ }^{\circ} \mathrm{C}$ for 1 minute, annealing at $50^{\circ} \mathrm{C}$ for shrimp-specific primers and at $55^{\circ} \mathrm{C}$ for universal fish primers for 1 minute, extension at $72^{\circ} \mathrm{C}$ for 1 minute 15 seconds, followed by post extension at $72^{\circ} \mathrm{C}$ for 7 minutes.

\section{Electrophoresis and sequencing}

The PCR products were observed on $0.8 \%$ agarose gel electrophoresis (Westermeier 2005). The electrophoresis was run with current of $65 \mathrm{~mA}$ and 100 -volt for $24 \mathrm{~min}$. The PCR products were visualized under UV light. Subsequently, the PCR products were sent for sequencing to the Firstbase (Malaysia).

\section{Bioinformatic analysis}

The COI sequences were aligned using MEGA 6 (Molecular Evolutionary Genetics Analysis) program (Tamura et al. 2013). BLAST was used to look for the resemblance species based on the homology of the resulting nucleotide base sequence. The nucleotide sequences of the sample were compared with the available data on GenBank. Phylogenetic tree was constructed using Neighbor-Joining tree method with bootstrap value 1000 . Qualitative data in visual form and profiles for DNA isolation and amplification and protein electropherogram are presented descriptively.

\section{RESULTS AND DISCUSSION}

\section{Profile of specific primer for shrimp}

The primer design was carried out by aligning and selecting the conserved areas of the shrimp COI genes. The sequence of shrimp COI gene based on the conserved area of Penaeus monodon (AF217843.1), Litopenaeus vannamei (EF584003.1), Litopenaeus stylirostris (EU517503.1), Fenneropenaeus merguiensis (KP637168.1), and Metapenaeus ensis (KP637170.1). The conserved areas for COI forward genes were obtained at the position of 118136 and COI reverse genes were obtained at the position of 716-731 bp, resulting in a 613 bp target gene. The evaluation of primer was conducted by OligoEvaluator ${ }^{\mathrm{TM}}$ software (Table 1).

The length of the forward primer was $18 \mathrm{bp}$ and the reverse primer was $16 \mathrm{bp}$. The primers were in the optimal size of 10-40 bp (Brodin et al. 2013). The melting temperature of the primers was $57.20^{\circ} \mathrm{C}$ and $57.80^{\circ} \mathrm{C}$, respectively. OligoEvaluator ${ }^{\mathrm{TM}}$ software calculated the melting temperature of the primers using the nearest neighbor method which takes into account the sequence of the oligonucleotide, thermodynamic as well as other factors that affect Tm, including oligonucleotide and monovalent cation concentrations rather than just the base composition.

Table 1. Primer evaluation of COI gene with OligoEvaluator ${ }^{\mathrm{TM}}$

\begin{tabular}{|c|c|c|c|c|c|c|}
\hline Primer & Sequence & Length (bp) & $\operatorname{Tm}\left({ }^{\circ} \mathbf{C}\right)$ & $\mathrm{GC} \%$ & Secondary structure & Primer dimer \\
\hline Forward & 5'-TCCGAGCTGAATTAGGTC-3' & 18 & 57.20 & 50.0 & No & No \\
\hline Reverse & 5’-TGGGTGACCGAAGAAT-3' & 16 & 57.80 & 50.0 & No & No \\
\hline
\end{tabular}


Table 2. Concentration and purity of DNA on shrimp crackers

\begin{tabular}{lcc}
\hline \multicolumn{1}{c}{ Samples } & $\begin{array}{c}\text { DNA concentration } \\
(\mathbf{n g} / \boldsymbol{\mu} \mathbf{L})\end{array}$ & $\begin{array}{c}\text { DNA Purity } \\
\left(\mathbf{A}_{\mathbf{2 6 0}} / \mathbf{A}_{\mathbf{2 8 0}}\right)\end{array}$ \\
\hline KU I & 2.6 & 1.02 \\
KU II & 1.8 & 1.12 \\
KU III & 0.3 & 8.41 \\
KU IV & 1.7 & 1.46 \\
KU V & 3.1 & 1.43 \\
KU VI & 2.2 & 2.50 \\
KU VII & 1.7 & 1.90 \\
KU VIII & 2.3 & 1.51 \\
KU IX & 1.3 & 0.97 \\
KU X & 2.7 & 0.89 \\
KU XI & 3.9 & 1.67 \\
KU XII & 8.1 & 1.84 \\
KU XIII & 1.3 & 1.27 \\
KU XIV & 2.5 & 2.85 \\
\hline
\end{tabular}

Note: KU I -KU XIV: Shrimp crackers with different brands

According to Borah (2011), the optimal forward and reverse primer melting temperature ranges from $52^{\circ} \mathrm{C}$ to $65^{\circ} \mathrm{C}$. The melting temperature is used to estimate the attachment temperature in the denatured DNA. A high melting temperature will produce a low PCR product, whereas a very low melting temperature causes a nonspecific product due to a large number of unsuitable base pairs (Wu et al. 1991).

The percentage of GC was $50 \%$ indicating the amount of guanine and cytosine content in the primer. The optimal $\mathrm{GC}$ percentage range is at $40-60 \%$, so the primers obtained are still within the recommended $\mathrm{GC} \%$ range (Lorenz 2012). GC base pairs have three stronger hydrogen bonds than the base pair of AT which has two hydrogens, thus increasing the efficiency of PCR processes (Yakovchuk et al. 2006).

\section{DNA concentration and purity}

The results of DNA concentration ranged between 0.3 to $8.1 \mathrm{ng} / \mu \mathrm{L}$ (Table 2). The DNA concentrations of the crackers were relatively low due to processing effects. The level of processing on food products affects the concentration of DNA obtained (Stevanofa et al. 2013). DNA concentration is also affected by the ingredients of the mixtures contained in the product. The additions of polysaccharides, proteins, or lipids and other ingredients in processed products cause the isolated DNA mix with contaminant compounds (Piskata et al. 2017). Maulid and Nurilmala (2015) reported that the processed mackerel cracker DNA product could not be observed on agarose gel electrophoresis due to low concentration.

The purity of the extracted DNA is important for the success of DNA barcoding. In this research, the purity of DNA was hampered by the chemical compounds present in food matrices. Of fourteen shrimp cracker samples, only two (KU VII and KU XII) had an ideal $\mathrm{A}_{260} / \mathrm{A}_{280}$ ratio (within 1.8-2.0 (Desjardins and Cocklins 2010), meanwhile, the other twelve samples had $\mathrm{A}_{260} / \mathrm{A}_{280}$ ratio outside the ideal range (Table 2). It is known that processing methods affect DNA quantity and quality, and different extraction methods are required to extract the DNA. Processing procedures could lead to DNA degradation, meanwhile filling media in the processed seafood affects the efficiency of DNA extraction process (Sajali et al. 2018). Piskata et al. (2019) compared eight DNA extraction procedures namely DNeasy Blood and Tissue Kit, DNeasy Mericon Food Kit, Chemagic DNA Tissue 10 Kit, Food DNA Isolation Kit, UltraPrep Genomic DNA Food Mini Prep Kit, High Pure PCR Template Preparation Kit, phenol-chloroform extraction, and NucleoSpin Food. They found that different extraction protocols produced different DNA yields. They also found that technological processing significantly affected the yield and quality of isolated DNA molecules, as well as the ability of DNA to undergo PCR amplification.

\section{DNA amplification}

Polymerase Chain Reaction (PCR) assay was conducted to amplify the DNA of shrimp crackers with specifically designed primers based on COI gene. The result of amplification of the COI genes in samples was visualized using $0.8 \%$ agarose gel, showing a single band at 500-750 bp for KU III, KU V, KU VI, KU VII, KU VIII, KU IX, KU X, and KU XIII (Figure 1.A). The DNA from samples KU I, KU II, KU IV, KU XI, KU XII, and KU XIV were not successfully amplified as indicated by the empty lane on the agarose. The absence of PCR products on these samples can be caused by two possible reasons. Firstly, these samples were contaminated by contaminations that could not be removed during the extraction process as indicated by the ratio of $\mathrm{A}_{260} / \mathrm{A}_{280}$. Polysaccharides, proteins, collagen, polyphenols, fulvic acids, or lipids are substances in food matrices that could affect the integrity of DNA or cause inhibition of subsequent PCR analysis (Piskata et al. 2017). Secondly, the purified DNA samples were not of shrimp origin. To test this hypothesis, PCR amplification was carried out to those samples using fish universal primer FishF2R2. Interestingly, a band belongs to KU IV appeared on the agarose gel indicating adulteration of shrimp cracker by fish meat (Figure 1.B). Adulteration of crustacean meat by fish meat had been reported in several publications. Previous researchers reported adulteration of blue swimmer (Portunus armatus) crab meat samples with surimi (Gayo et al. 2006; Gayo and Hale 2007).

\section{Species identification}

The identification of species using BLAST showed the sample had identity levels $96-100 \%$ with three species of shrimp and one fish species. Other studies of shrimp identification resulted in $83-100 \%$ identity in Penaeidae (Rajkumar et al. 2015) and 83-99\% in the Palaemonidae family (Udayasuriyan et al. 2015). Sample KU III, KU VI, KU VII, and KU XIII were identified as Litopenaeus vannamei, the KU V sample was identified as Metapenaeus ensis, samples KU VIII, KU IX, and KU X were identified as Fenneropenaeus merguiensis. The KU XIV sample was not identified as a shrimp cracker, but as a yellow-tailed barracuda (Sphyraena flavicauda) (Table 3). 


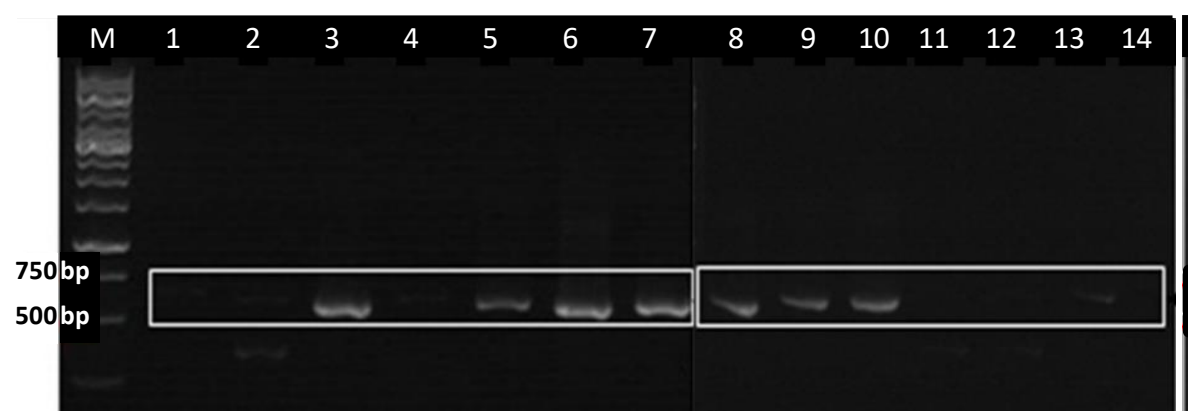

$\mathbf{A}$

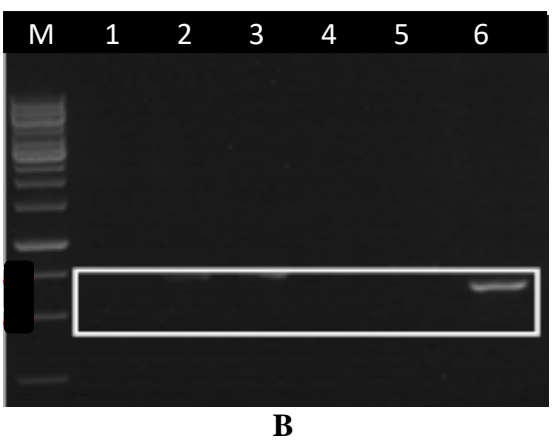

Figure 1. Electropherogram on $0.8 \%$ agarose gel of: A. Shrimp cracker samples using a specific designed primer of COI. M. Marker, 1. KU I; 2. KU II; 3. KU III; 4. KU IV; 5. KU V; 6. KU VI; 7. KU VII; 1. KU VIII; 2. KU IX; 3. KU X; 4. KU XI; 5. KU XII; 6. KU XIII; 7. KU XIV. B. Primer of FishF2R2. M. Marker, 1. KU I; 2. KU II; 3. KU IV; 4. KU XI; 5. KU XII; 6. KU XIV. Note: KU I -KU XIV: Shrimp crackers with different brands. White boxes: targeted gene

Table 3. Species identification by BLAST analysis

\begin{tabular}{|c|c|c|c|c|c|}
\hline \multirow{2}{*}{ Sample } & \multicolumn{2}{|c|}{ Analysis result } & \multirow{2}{*}{ Homology } & \multirow{2}{*}{ E value } & \multirow{2}{*}{$\begin{array}{c}\text { Accession } \\
\text { number }\end{array}$} \\
\hline & Common name & Species & & & \\
\hline KU III & Vannamei shrimp & Litopenaeus vannamei & $99 \%$ & 0 & KT596762.1 \\
\hline KU V & Rock shrimp & Metapenaeus ensis & $98 \%$ & 0 & KP637170.1 \\
\hline KU VI & Vannamei shrimp & Litopenaeus vannamei & $99 \%$ & 0 & KT596762.1 \\
\hline KU VII & Vannamei shrimp & Litopenaeus vannamei & $100 \%$ & 0 & KT596762.1 \\
\hline KU VIII & Jerbung Shrimp & Fenneropenaeus merguiensis & $99 \%$ & 0 & KP637168.1 \\
\hline KU IX & Jerbung Shrimp & Fenneropenaeus merguiensis & $98 \%$ & 0 & KP637168.1 \\
\hline KU X & White shrimp & Fenneropenaeus merguiensis & $96 \%$ & 0 & KP637168.1 \\
\hline KU XIII & Vannamei shrimp & Litopenaeus vannamei & $99 \%$ & 0 & KT596762.1 \\
\hline KU XIV & Yellowtail barracuda & Sphyraena flavicauda & $100 \%$ & 0 & KF715026.1 \\
\hline
\end{tabular}

Note: KU I -KU XIV: Shrimp crackers with different brands

Litopenaeus vannamae, F. merguiensis, and M. ensis are widely distributed throughout the Indonesian coastal area. L. vannamei, in particular, is the most common species produced in Indonesia. Species identification using COI gene has been successfully applied to various seafood products. Jaikumar et al. (2019) could authenticate six frozen shrimp species packed and sold by different commercial companies. Meanwhile, Abdullah et al. (2020) found the illegal application of endangered shark species, Sphyrna lewini, Alopias pelagicus, and Carcharhinus falciformis in processed fishery products.

Genetic distance analysis was performed using the pairwise distance substitution model. The genetic distance can be used to determine the relationships between samples The genetic distance between samples identified as shrimp (KU III, KU V, KU VI KU VIII, KU IX, KU X, and KU XIII) ranges from 0.000-0.186 (Table 4). The KU XIV sample identified as a fish has a genetic distance of more than 0.300 against another sample. Sample KU III, KU VII, and KU XIII had a genetic distance value of 0.00 indicating the same species was used as the ingredient of the crackers. The samples identified in L. vannamei species had an average genetic distance of 0.038 , whereas the $F$. merguiensis species had an average genetic distance of
0.049. The genetic distance between L. vannamei and $M$. ensis species (0.167) was greater than the genetic distance $L$. vannamei with $F$. merguiensis $(0.127)$. This signifies the $L$. vannamei kinship closer to $F$. merguiensis compared to M. ensis. Quan et al. (2004) stated genetic distance between genus in shrimp ranged $18.67 \%-31.87 \%$ influenced by kinship and place of origin. Genetic distance measures the differences in the sequence of DNA samples. The magnitude of the distances reflects the number of changes (base substitutions and insertion/deletion events) as a proportion of the overall sequence length. Table 4 shows the intra-species genetic distances are in agreement with Francisco and Junior (2005) where they found the genetic distances between two shrimp species L. vannamei and Farfantepenaeus subtilis were about $10 \%$. Meanwhile, the genetic distances of KU XIV and other DNA samples are large due to inter-species variability. This inter-species variability is responsible for large genetic distance values as shown by Ude et al. (2020).

The base composition of mt-COI gene sequences varied among DNA samples. The aligned nucleotide lengths were 463-597 bp with purine composition 45.6\% (adenine $27.8 \%$, guanine $17.8 \%$ ) and pyrimidine $54.4 \%$ (thymine $33.0 \%$, cytosine $21.4 \%$ ). The number of pyrimidine 
nucleotide bases in one more DNA thread than purine (Table 5). Lin et al. (2008) stated that collected DNA samples showed more pyrimidine base amounts than purine bases. The last nucleotide base is guanine $(\mathrm{G})$ with an average of 16.8. This result is in accordance with Zhang et al. (2010) which states that the guanine base $(\mathrm{G})$ has the least amount. The AT bias in COI gene of shrimp crackers varied from $59.2 \%$ to $63.2 \%$ and the GC bias varied from $36.2 \%$ to $39.3 \%$. High AT bias indicates a lower abundance of nuclear copies in the COI gene (NUMTs), known as a pseudogene (Jaikumar et al. 2019). High AT bias has also been reported in several crustacean species including marine crabs prawns (Udayasuriyan et al. 2015), freshwater crabs (Bhavan et al. 2015), and freshwater (Umamaheswari et al. 2016).

The phylogenetic tree was constructed using NeighborJoining Tree (NJT) method with the bootstrap 1000 and pdistance model (Figure 2). The NJT method is able to calculate the kinship distance indicated by the bootstrap value (Rusinko and McPartlon 2017). The shrimp sequences were aligned with the ingroup and outgroup. The species of sea cucumber (Holothuria leucospilota) was the outgroup since it has a distant kinship with the sample to show the whole phylogenetic tree.

Table 4. Genetic distance of COI gene of shrimp crackers

\begin{tabular}{|c|c|c|c|c|c|c|c|c|c|}
\hline & KU III & KU V & KU VI & KU VII & KU VIII & KU IX & KU X & KU XIII & KU XIV \\
\hline \multicolumn{10}{|l|}{ KU III } \\
\hline KU V & 0.186 & & & & & & & & \\
\hline KU VI & 0.076 & 0.149 & & & & & & & \\
\hline KU VII & 0.000 & 0.186 & 0.076 & & & & & & \\
\hline KU VIII & 0.161 & 0.117 & 0.090 & 0.161 & & & & & \\
\hline KU IX & 0.164 & 0.130 & 0.090 & 0.164 & 0.027 & & & & \\
\hline KU X & 0.109 & 0.115 & 0.046 & 0.109 & 0.061 & 0.061 & & & \\
\hline KU XIII & 0.000 & 0.186 & 0.076 & 0.000 & 0.161 & 0.164 & 0.108 & & \\
\hline KU XIV & 0.325 & 0.311 & 0.301 & 0.325 & 0.291 & 0.306 & 0.308 & 0.325 & \\
\hline
\end{tabular}

Table 5. Nucleotide composition of COI gene of shrimp cracker

\begin{tabular}{|c|c|c|c|c|c|}
\hline Sample & $\begin{array}{c}\text { Thymine (T) } \\
(\%)\end{array}$ & $\begin{array}{c}\text { Cytosine (C) } \\
(\%)\end{array}$ & $\begin{array}{c}\text { Adenine (A) } \\
(\%)\end{array}$ & $\begin{array}{c}\text { Guanine (G) } \\
(\%)\end{array}$ & $\begin{array}{c}\text { Total } \\
\text { (bp) }\end{array}$ \\
\hline KU III (L. vannamei) & 34.2 & 19.8 & 27.7 & 18.2 & 555 \\
\hline KU V (M. ensis $)$ & 30.4 & 22.4 & 29.2 & 17.9 & 575 \\
\hline KU VI (L. vannamei) & 32.6 & 20.1 & 30.6 & 16.6 & 571 \\
\hline KU VII (L. vannamei) & 35.0 & 19.8 & 27.8 & 17.4 & 529 \\
\hline KU VIII (F. merguiensis) & 32.3 & 20.7 & 28.4 & 18.6 & 585 \\
\hline KU IX (F. merguiensis) & 34.5 & 20.2 & 28.6 & 16.7 & 455 \\
\hline KU X (P. merguensis) & 31.7 & 21.0 & 31.1 & 16.2 & 463 \\
\hline KU XIII (L. vannamei) & 35.3 & 19.8 & 27.7 & 17.1 & 537 \\
\hline KU XIV (S. flavicauda) & 28.3 & 29.1 & 23.3 & 19.3 & 597 \\
\hline
\end{tabular}

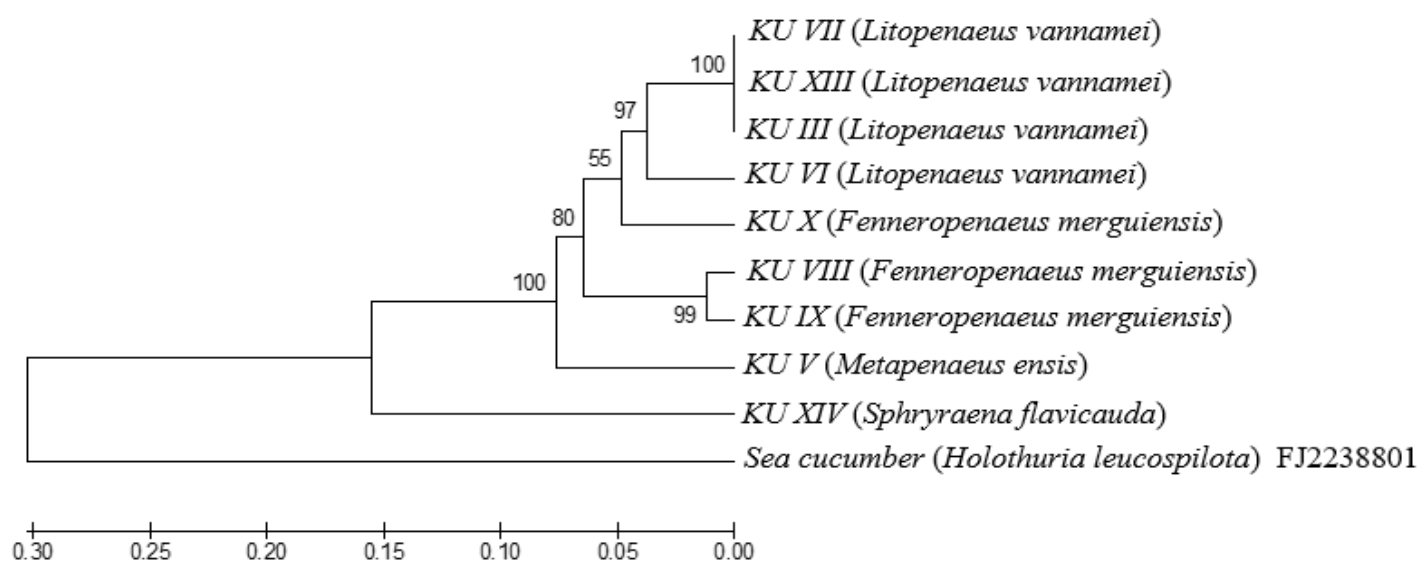

Figure 2. Phylogenetic tree based on COI gene 
The samples identified as shrimp formed distinct clusters consisting of $L$. vannamei and $F$. merguiensis, while the $M$. ensis species were separated from other shrimp groups. Other studies have demonstrated phylogeny trees with sequences among genera Penaeus, Fenneropenaeus, and Metapenaeus (Rajkumar et al. 2015); Litopenaeus and the adjacent Fenneropenaeus belong to the old Penaeus genus, and Metapenaeus are separate from the other two genera (Voloch et al. 2005). The short evolutionary distance is shown by short branches in phylogenetic tree indicating close genetic and kinship (Rusinko and McPartlon 2017). The position of groups KU III, KU VI, KU VII, and KU XIII with the position of KU $\mathrm{X}$ was most unstable marked with the smallest bootstrap value $(55 \%)$, similar to the group positions KU VIII and KU IX.

In conclusion, specific shrimp primers have been successfully designed and amplified eight samples of shrimp crackers. Molecular identification showed eight samples using shrimp and one sample using fish ( $S$. Flavicauda) as the raw material. These results indicate illegal substitution of shrimp using unidentified species has occurred in shrimp crackers.

\section{ACKNOWLEDGEMENTS}

This study was supported by the Ministry of Research, Technology and Higher Education (RISTEK-BRIN) 2020, Indonesia for MN.

\section{REFERENCES}

Abdullah A, Nurilmala M, Muttaqin E, Yulianto I. 2020. DNA-based analysis of shark products sold on the Indonesian market toward seafood labelling accuracy program. Biodiversitas 21 (4): 1385-1390. DOI: $10.13057 /$ biodiv/d210416.

Abdullah A, Sativa HA, Nurhayati T, Nurilmala M. 2019. DNA barcoding application for seafood label traceability of various commercial surimi-based products. Indon Fish Res J 22 (3): 508-519. DOI: 10.17844/jphpi.v22i3.28950.

Adibah AB, Syazwan S, Hanim MZH, Munir MZB, Faraha AGI, Azizah MNS. 2020. Evaluation of DNA barcoding to facilitate the authentication of processed fish products in the seafood industry. Int J Food Sci Technol 129: 1-7. DOI: 10.1016/j.lwt.2020.109585.

Álvarez-Fernández R. 2013. Explanatory chapter: PCR primer design. Meth Enzymol 529: 1-21. DOI: 10.1016/B978-0-12-418687-3.00001$\mathrm{X}$.

Amaral CRL, Maciel V, Silva DA, Amorim A, Carvalho EF. 2017. Tuna fish identification using mtDNA markers. Forensic Sci Int Genet Suppl Ser 6: 471-473. DOI: 10.1016/j.fsigss.2017.09.193.

Barcaccia G, Lucchin M, Cassandro M. 2015. DNA barcoding as a molecular tool to track down mislabeling and food piracy. Diversity 8: 1-16. DOI: 10.3390/d8010002.

Bhavan PS, Umamaheswari S, Udayasuriyan R, Rajkumar G, Amritha H, Saranya K. 2015. Discrimination of two freshwater crabs Spiralothelphusa hydrodroma and Barytelphusa jacquemontii and one mangrove crab Neosarmatium asiaticum by DNA barcoding of MTCOI gene. J Chem Biol 5:1426-40.

Borah P. 2011. Primer designing for PCR. Sci Vis 11: 134-136.

Brodin J, Mohan K, Gayathri A, Will F, Peter H, Cheryl G, Lance G, Bette K, Thomas T. 2013. A multiple-alignment based primer design algorithm for genetically highly variable DNA targets. BMC Bioinformatics 14 (1): 255-263. http://www.biomedcentral.com/1471$2105 / 14 / 255$
Calosso MC, Claydon JAB, Mariani S, Cawthorn D. 2020. Global footprint of mislabelled seafood on a small island nation. Biol Conserv 245: 1-9. 10.1016/j.biocon.2020.108557.

Carvalho CD, Palhares RM, Drummond MG, Frigo TB. 2015. DNA barcoding identification of commercialized seafood in South Brazil: a governmental regulatory forensic program. Food Control 50: 784788. DOI: 10.1016/j.foodcont.2014.10.025.

Ceruso M, Mascolo C, De Luca P, Venuti I, Smaldone G, Biffali E, Anastasio A, Pepe T, Sordino P. 2020. A rapid method for the identification of fresh and processed Pagellus erythrinus species against frauds. Foods 9: 1-15. DOI:10.3390/foods9101397.

Corrado F, Cutarelli A, Criscuolo D, Roma AD, Cecere B, Simonetti D, Galiero G, Coccia E, Viola C, Varrichio E, Paolucci M. 2016. Identification of fraud in trade in processed fish products by DNA analysis. Imekofoods 2: 1-4.

Desjardins P, Conklin D. 2010. Nanodrop microvolume quantitation of nucleic acids. J Vis Exp 45:1-5. DOI: 10.3791/2565.

Destrasia RF. 2012. Comparative study of shrimp head prawn manufacture with composite flour. Food Sci Culinary Education J 1: $1-5$.

Francisco AKD, Junior PMG. 2005. Genetic distance between broodstocks of the marine shrimp Litopenaeus vannamei (Decapoda, Penaeidae) by mtDNA analyses. Genet Mol Biol 28 (2): 258-261. DOI: $10.1590 /$ S1415-47572005000200014.

Gayo J, Hale SA, Blanchard SM. 2006. Quantitative Analysis and Detection of Adulteration in Crab Meat Using Visible and NearInfrared Spectroscopy. J Agric Food Chem 54: 1130-1136. DOI: 10.1021/jf051636i.

Gayo J, Hale SA. 2007. Detection and Quantification of Species Authenticity and Adulteration in Crabmeat Using Visible and NearInfrared Spectroscopy. J Agric Food Chem 55: 585-592. DOI: $10.1021 /$ jf061801+

Hanifaturahmah F, Perwitasari-Farajallah DP, Nurlisa BA, Nurilmala M, Sudrajat A. Ochiai Y. 2020. Morphological and molecular identification of seahorses (Hippocampus spp.) from the coast of Sumatra Island, Indonesia. Biodiversitas 21 (9): 4116-4123. DOI: 10.13057/biodiv/d210924

Jaikumar IM, Periyakali SB, Rajendran US, Ramasamy K. 2019. Authentication of commercially available frozen shrimp meats using DNA barcoding. J Appl Biol 7 (06): 79-87. DOI: 10.7324/JABB.2019.70613.

KKP. 2020. $1^{\text {st }}$ Quarter 2020, the value of fisheries export reached USD 1.24 billion. Marine and Fisheries Ministry of Republic Indonesia. Jakarta. [Indonesian].

Lin WF, Hwang DF. 2008. A multiplex of PCR assay for species identification of raw and cooked Bonito. Food Control 19 (9): 879855. DOI: $10.1016 /$ j.foodcont.2007.08.015.

Lorenz TC. 2012. Polymerase Chain Reaction: basic protocol plus troubleshooting and optimization strategies. J Vis Exp 63: 1-15. DOI: $10.3791 / 3998$.

Maulid DY, Nurilmala M. 2015. DNA Barcoding for authentication of mackerel (Scomberomorus sp.) products. J Akuatika 6: 154-160.

Nurilmala M, Ochiai Y. 2016. Molecular characterization of southern bluefin tuna myoglobin (Thunnus maccoyii). Fish Physiol Biochem 42 (5): 1407-1416. DOI: 10.1007/s10695-016-0228-0.

Nurilmala M, Widyastuti U, Kusuma WA, Nurjanah, Wulansari N, Widyatuti Y. 2016. DNA barcoding for identification of processed tuna fish in Indonesian market. J Teknol 78 (4-2): 115-118.

Nurilmala M, Sari EM, Hizbullah H, Abdullah A, Nurlisa BA, Sudrajat A. 2020. DNA barcoding for seahorse identification and its potential as antioxidant and stimulant indicator. IOP Conf. Ser.: Earth Environ. Sci.404 012002 .

Palanisamy SK, Kumar CP, Paramasivam P, Sundaresan U. 2020. DNA barcoding of horn snail Telescopium telescopium (Linnaeus C, 1758) using mt-COI gene sequences. Reg Stud Mar Sci 35: 1-7.

Paquin MM, Buckley TW, Hibpshman RE, Canino MF. 2014. DNAbased identification methods of prey fish from stomach contents of 12 species of eastern North Pacific groundfish. Deep-Sea Res Part I Oceanogr Res Pap 85: 110-117. DOI: 10.1016/j.dsr.2013.12.002.

Piskata Z, Pospisilovaa E, Borilova G. 2017. Comparative study of DNA extraction methods from fresh and processed yellowfin tuna muscle tissue. Int $\mathrm{J}$ Food Prop 20 (1): 430-443. DOI: 10.1080/10942912.2017.1297953.

Piskata Z, Servusova E, Babak V, Nesvadbova M, Borilova G. 2019. The Quality of DNA isolated from processed food and feed via different 
extraction procedures. Molecules 24: 1188-1197. DOI: 10.3390/molecules24061188.

Pollack SJ, Kawalek MD, Williams-Hill DM, Hellberg. 2018. Evaluation of DNA barcoding methodologies for the identification of fish species in cooked products. Food Control 10: 297-304. DOI 10.1016/j.foodcont.2017.08.013

Quan J, Zhuang Z, Deng J, Dai J, Zhang Y. 2004. Phylogenetic relationship of 12 Penaeoidea shrimp species deduced from mitochondrial DNA sequences. Biochem Genet 42 (9/10): 331-345. DOI: 10.1023/B:BIGI.0000039808.12069.ed

Rajkumar G, Bhavan PS, Udayasuriyan R, Vadilagan. 2015. Molecular identification of shrimp species, Penaeus semisulcatus, Metepenaeus dobsoni, Metapenaeus brevicornis, Fenneropenaeus indicus, Parapenaeopsis sylifera, and Solenocera crassicornis inhabiting in the coromandel coast (Tamil Nadu, India) using MT-COI gene. Int J Fish Aquat 2 (4): 96-106.

Rusinko J, McPartlon M. 2017. Species tree estimation using Neighbor Joining. J Theor Biol 414: 5-7. DOI: 10.1016/j.jtbi.2016.11.005

Sajali N, Wong SC, Hanapi UK, Jamaluddin SAB, Tasrip NA, Desa MNM. 2018. The challenges of DNA extraction in different assorted food matrices: A review. J Food Sci 10: 2409-2414.

Scarano D, Rao R. 2014. DNA markers for food products authentication. Diversity 6: 579-596. DOI:10.3390/d6030579.

Shokralla S, Hellberg RS, Handy SM, King I, Hajibabaei M. 2015. A DNA minibarcoding system for authentication of processed fish products. Sci Rep 5: 1-11. DOI: 10.1038/srep15894.

Stevanofa P, Taseva M, Georgieva T, Gotcheva V, Angelov A. 2013. A modified CTAB method for DNA extraction from soybean and meat products. Biotechnol Biotechnol Equip 27 (3): 3803-3810. DOI: 10.5504/BBEQ.2013.0026

Sutrisno H. 2015. Phylogenetic relationships Withinarctornis (Lepidoptera: Erebidae) based on COI gene sequences. Hayati J Biosci 22 (1): 6-11. DOI: 10.4308/hjb.22.1.6.
Tamura K, Stecher G, Peterson D, Filipski A, Kumar S. 2013. MEGA6: Molecular evolutionary genetics analysis version 6.0. Mol Biol Evol 30 (12): 2725-2729. DOI: 10.1093/molbev/mst197.

Udayasuriyan R, Bhavan PS, Vadivalagan C, Rajkumar G. 2015. Efficiency of different COI markers in DNA barcoding of freshwater prawn species. J Entomol Zool 3 (3): 98-110.

Ude GN, Igwe DO, Brown C, et al. 2020. DNA barcoding for identification of fish species from freshwater in Enugu and Anambra States of Nigeria. Conserv Genet Resour 12: 643-658. DOI: 10.1007/s12686-020-01155-7.

Umamaheswari S, Bhavan PS, Udayasuriyan R, Vadivalagan C, Kalpana R. 2016. Discrimination of four marine crabs and one freshwater crab through mt-COI gene. J Entomol Zool Stud 4 (5):766-82.

Voloch CM, Freire PR, Russo CAM. 2005. Molecular phylogeny of penaeid shrimp inferred from two mitochondrial markers. Genet Mol Res 4 (4): 668-678.

Westermeier R. 2005. Electrophoresis in Practice. Wiley-VCH, Weinheim (GE).

Wu DY, Ugozzoli L, Pal BK, Qian J, Wallace RB. 1991. The effect of temperature and oligonucleotide primer length on the specificity and efficiency of amplification by the polymerase chain reaction. DNA Cell Biol 10 (3): 233-240. DOI: 10.1089/dna.1991.10.233.

Xiong X, Huang M, Yuang F, Lu L, Xiong X. 2019. Development and validation of a fast DNA extraction protocol for fish products. Food Anal Methods 10: 1-11. DOI: 10.1007/s12161-019-01554-z.

Yakovchuk P, Ekaterina P, Maxim DF-K. 2006. Base-stacking and basepairing contributions into thermal stability of the DNA double helix. Nucleic Acid Res 34 (2): 564-574. DOI: 10.1093/nar/gkj454.

Zhang Q, Cheng Q, Guan W. 2010. Mitochondrial COI gene sequence variation and taxonomic status of three Macrobrachium species. Zool Res 30 (6): 613-619. DOI: 10.3724/SP.J.1141.2009.06613. 